\title{
Mapping of the $\mathrm{CO}_{2}$ storage potential in the Nordic region
}

\author{
Karen Lyng Anthonsen, Peter Frykman and Carsten Møller Nielsen
}

The concept of utilising available pore space in deep saline sandstone aquifers for storage of $\mathrm{CO}_{2}$ was recognised in the late 1980s. In 1996, the first commercial $\mathrm{CO}_{2}$ storage project began with injection into sandstones of the Utsira Formation in Norway. The formation is located above the Sleipner Formation from where the Sleipner field produces natural gas. The project was initiated due to a high $\mathrm{CO}_{2}$ content of the natural gas, which was subjected to a Norwegian offshore carbon tax. The natural gas is produced on the Sleipner platform where the $\mathrm{CO}_{2}$ is separated, captured and reinjected from a neighbouring platform. The potential for using the technology to reduce $\mathrm{CO}_{2}$ emissions from large stationary point sources initiated many research projects aimed at mapping areas with potential $\mathrm{CO}_{2}$ storage capacity around the world.

In 2008, the Nordic countries decided to set up a special venture for climate, energy and the environment by launching the Top-Level Research Initiative promoting research within six sub-programmes, including one on Carbon, Capture and Storage (CCS). With this background the Nordic CCS Competence Centre (NORDICCS) was initiated in 2011, involving major Nordic CCS research institutes, industry and stakeholders. One of the main outcomes of the project, which terminated in 2015, is a webbased Nordic $\mathrm{CO}_{2}$ Storage Atlas (data.geus.dk/nordiccs/ map.xhtml), which aims to make CCS-related data and interpretations available to decision makers and the public.

The newly released atlas combines data from previous $\mathrm{CO}_{2}$ storage screening and mapping projects (GESTCO, EU GeoCapacity and the Norwegian $\mathrm{CO}_{2}$ Storage Atlas) with new data for areas not previously covered. The atlas gives an overview of storage options and the associated reservoir properties in Denmark, Norway, Sweden and Iceland.

\section{$\mathrm{CO}_{2}$ storage site screening in the Nordic region}

The project focused on $\mathrm{CO}_{2}$ storage (1) in sandstone aquifers, (2) by chemical reaction in basalts and (3) in depleted hydrocarbon fields. Large-scale geological storage of $\mathrm{CO}_{2}$ in sandstone aquifers requires the presence of a porous and permeable subsurface layer, a burial depth of minimum $800 \mathrm{~m}$ to keep the $\mathrm{CO}_{2}$ as a dense phase, and an adequate top seal preventing the buoyant $\mathrm{CO}_{2}$ from migrating to the surface. Areas with the largest storage potential are associated with sedimentary basins containing widespread sandstone layers. Sedimentary basins with storage potential are situated as a marginal belt around the Scandinavian peninsula from the Baltic Sea, through Denmark and along the Norwegian coast, whereas the shallow sedimentary basins in Finland are not considered appropriate for $\mathrm{CO}_{2}$ storage (Teir et al. 2010). In Iceland, the storage potential is not related to sedimentary basins, but to injection of $\mathrm{CO}_{2}-$ saturated water into porous basalts (Fig. 1). The dissolved $\mathrm{CO}_{2}$ reacts with divalent cations in the basalt-forming stable carbonate minerals such as calcite, dolomite, magnesite, siderite, and $\mathrm{Mg}$-Fe carbonate solid solutions (Gislason et al. 2010).

Compared to storage in saline aquifers, the $\mathrm{CO}_{2}$ storage capacity in hydrocarbon fields is in general minor, but late-

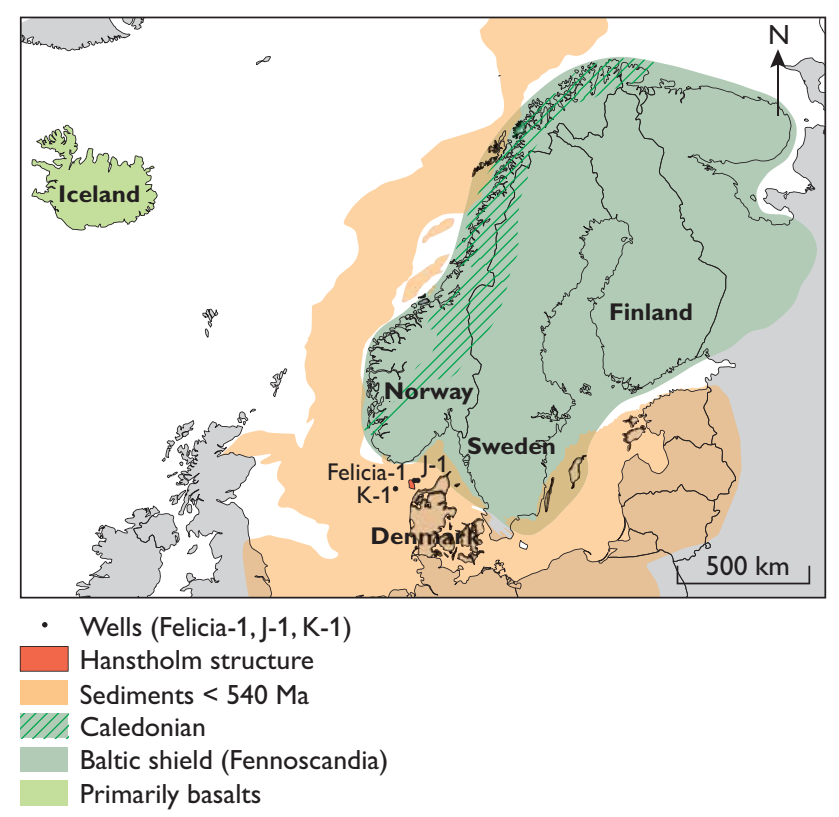

Fig. 1. Generalised geological overview of the Precambrian Baltic shield and the sedimentary basins. 
stage oil production may profit from enhanced oil recovery (EOR) by injection of $\mathrm{CO}_{2}$. Thus the highest potential for industrial-scale storage is obtained when EOR is used in connection with the $\mathrm{CO}_{2}$ storage. The geological and engineering knowledge accumulated from producing oil and gas fields is also more detailed than for aquifer storage sites.

The data compiled in the web-based atlas include an approximate outline of storage formations and aquifers with information for each unit on depth, thickness, lithology, proportion of sand, age and reservoir type, based on well data and seismic interpretations. Furthermore, reservoir properties such as porosity, permeability, salinity, $\mathrm{CO}_{2}$ density, storage efficiency factor and estimated storage capacity are listed. In order to illustrate the geological complexity, major faults are included in the atlas. Likewise, an outline of the sealing formations is included in order to indicate storage integrity.

The compiled data were used to characterise and rank storage formations and traps and to calculate $\mathrm{CO}_{2}$ storage capacities. The ranking criteria were grouped into four main categories: reservoir properties, seal properties, safety/ risk and maturity/data coverage. This resulted in a selection of the most prospective Nordic storage areas, based on available geological knowledge up to 2014 (Anthonsen $e t$ al. 2014). The ranking revealed that the most prospective storage areas are found in the Norwegian North Sea. This is basically a result of the knowledge from the intensive oil and gas exploration making the Norwegian areas more mature for exploitation of storage capacity. It has to be stressed that there are large uncertainties in many of the evaluated parameters and that more data and further data analysis are required before any of the sites are ready for $\mathrm{CO}_{2}$ injection.

\section{Mapped $\mathrm{CO}_{2}$ storage capacity}

The storage capacity estimates make use of the same methodology as the EU GeoCapacity project; see VangkildePedersen et al. (2009). The total mapped $\mathrm{CO}_{2}$ storage capacity for Denmark, Norway and Sweden is 134000 megaton $(\mathrm{Mt})$. The storage capacity related to saline aquifers is $120000 \mathrm{Mt}$, with $22000 \mathrm{Mt}$ in Denmark, 94600 Mt in Norway (hereof $72800 \mathrm{Mt}$ in the North Sea) and $3400 \mathrm{Mt}$ in Sweden. The total number includes 14000 Mt in hydrocarbon fields, with $2000 \mathrm{Mt}$ in Denmark and 12000 Mt in Norway (Røkke et al. in press; Fig. 2).

It should be emphasised that the presented storage capacities are regarded as simple estimates based on volumetric calculations of the available pore space and multiplied with a storage efficiency factor. Improved geological data and reservoir modelling work will be necessary to narrow

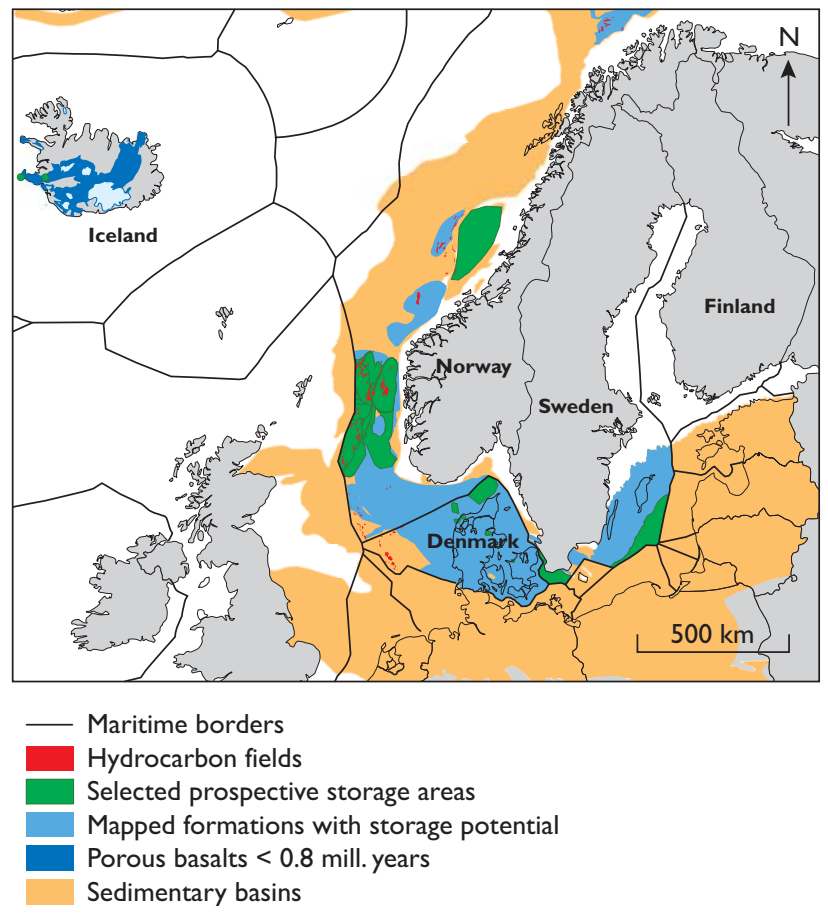

Fig. 2. All mapped Nordic $\mathrm{CO}_{2}$ storage formations (blue) and the selected most prospective areas in green. The dark blue area in Iceland is the highly porous basalt areas considered most promising for $\mathrm{CO}_{2}$ injection.

the specific uncertainties for the storage capacity estimates. Storage capacity estimates for porous basalts are based on a different methodology, and for onshore Iceland the calculated capacity ranges between 21000 and $400000 \mathrm{Mt}$ depending on the calculation approach (Snæbjörnsdóttir et al. 2014).

The storage capacity has to be seen in relation to the $\mathrm{CO}_{2}$ emission, which was $152.8 \mathrm{Mt}$ in 2011 for all large stationary point sources (emission $>70 \mathrm{Kt}$ ) in the five Nordic countries, with 25.8 Mt in Denmark, 55.6 Mt in Finland, 1.6 Mt in Iceland, 23.1 Mt in Norway and 46.6 Mt in Sweden. On a European scale the total emission from stationary point sources mapped in the EU GeoCapacity project was $2000 \mathrm{Mt}$ (Anthonsen et al. 2011), implying that theoretically all $\mathrm{CO}_{2}$ emissions for 70 years from these sources in Europe could be stored in the Nordic region.

\section{Modelling $\mathrm{CO}_{2}$ storage capacity in Denmark}

The procedure for the estimation of storage capacity is illustrated by a case study of the Hanstholm structure, using simple, static calculations supplemented with dynamic simulations. The dynamic simulation has the advantage that both reservoir properties such as heterogeneity and 
Fig. 3. A: Maps with depth contours for the top reservoir level and the position of the seven injection wells. The seven wells were positioned by iteration to effectively fill most of the structure. B: An optimum filling simulation of the Hanstholm structure. Injection period is 40 years.
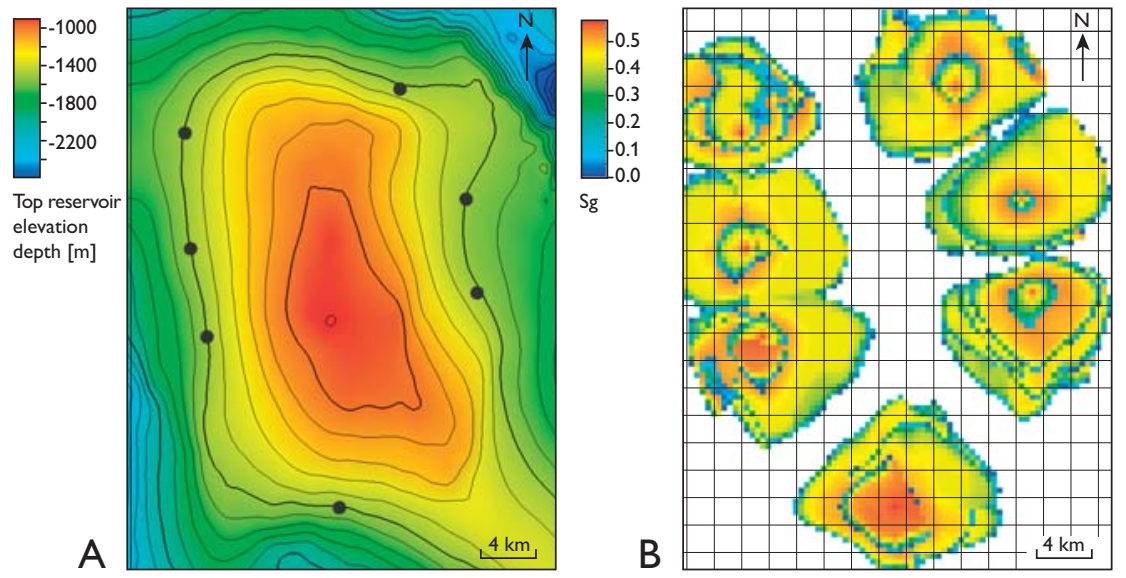

operational conditions can be accounted for, leading to a more realistic capacity number. The dynamic assessment requires that a 3D reservoir model is constructed, as it involves flow and pressure calculations over the time span of the operational period. The background for constructing this model is briefly described here.

The informal name Hanstholm structure is used for an offshore domal closure covering $603 \mathrm{~km}^{2}$, situated offshore c. $40 \mathrm{~km}$ north-west of the city of Hanstholm (Fig. 1). The water depth at the site is $c .30 \mathrm{~m}$. The target for storage is Upper Triassic - Lower Jurassic sandstones of the Gassum Formation. This formation consists of fine- to mediumgrained, locally coarse-grained sandstones interbedded with heteroliths, claystones and locally thin coal beds (Michelsen et al. 2003; Nielsen 2003). The sandstones were deposited by repeated progradation of shoreface and deltaic units forming laterally continuous sheet sandstones separated by offshore marine claystones. Fluvial sandstones dominate in the lower part of the formation as in most of the Fennoscandian Border Zone. The structure is situated close to the edge of the Fjerritslev Fault of the Sorgenfrei-Tornquist zone, and is formed by uplift due to post-depositional salt tectonics. The structure is interpreted from the depth structure map of the 'Top Triassic' as defined by Japsen \& Langtofte (1991), and has been used as a template for defining top and bottom of a reservoir with uniform thickness.

The depth to top reservoir is approximately $890 \mathrm{~m}$ below mean sea level, and the deepest closing contour is at approximately $1330 \mathrm{~m}$ (Fig. 3A). The theoretical spill point is situated at the south-eastern flank of the structure spilling into the Thisted domal structure.

The structure has not been drilled and data for the reservoir have to be extrapolated from information from the nearby Felicia-1, J-1 and K-1 wells (Fig. 1). It should be noted, however, that Felicia-1 is drilled at the crest of a rotated fault block, and is believed to show an extraordinarily large thickness of the Gassum Formation with a thick mudstone in the middle part, reflecting topographic influence from the nearby salt pillow during deposition. This may result in marked differences in reservoir properties between this well and the undrilled structure. The well J-1 some 30-40 $\mathrm{km}$ to the north-east has therefore been used as a template for the sand-shale sequence in the reservoir model. The claystones of the Fjerritslev Formation form the top seal of the aquifer. The Fjerritslev Formation is expected to be c. $500 \mathrm{~m}$ thick above the Hanstholm aquifer.

The reservoir model was used for a capacity study by simulating seven injection wells around the perimeter of the flank, and their positions were optimised by iteration to give the most complete filling pattern on the structure (Fig. 3B). $\mathrm{CO}_{2}$ was injected at a constant rate of $4.2 \mathrm{Mt}$ per well per year. The dynamic simulations account for an injection period of 40 years and with a preconditioned safety

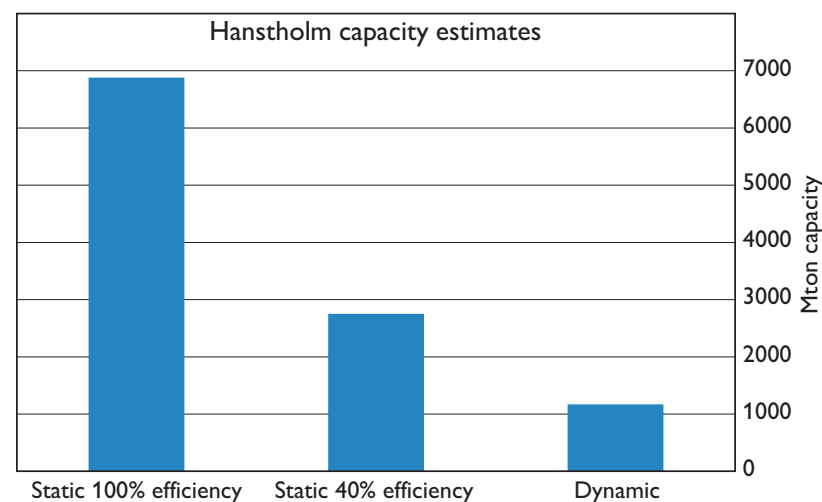

Fig. 4. Comparison of different capacity estimates including values from the dynamic simulation of optimum filling of the Hanstholm structure in Denmark. The previous estimate was based on static calculations and an assumed effieciency factor of $40 \%$. 
margin of the allowed pressure increase set to maximum $85 \%$ of the lithostatic pressure below the cap rock in order to avoid any fracture propagation in the cap rock. The resultant storage capacity was $1170 \mathrm{Mt} \mathrm{CO}_{2}$, but a change of the safety margin will naturally influence the storage capacity. The derived dynamic capacity for the Hanstholm structure can be compared to previous estimates of 2753 Mt based on the static model characteristics and an assumed efficiency factor; in this case $40 \%$ efficiency (Fig. 4) as described by Larsen et al. (2003).

\section{Summary}

Mapping of sandstone units (aquifers) and their associated reservoir properties have resulted in a web-based $\mathrm{CO}_{2}$ storage atlas. The reservoir data and properties were used to characterise and rank the potential storage areas and sites in an attempt to point out the most prospective ones based on currently available geological knowledge (Fig. 2). It is essential for the development of a $\mathrm{CO}_{2}$ storage site to know how much capacity is available. In the initial screening phase static theoretical estimates are used, but dynamic modelling of $\mathrm{CO}_{2}$ injection is very important in order to narrow the uncertainties of the storage capacities. The reduction in total storage capacity from previously published static calculations to the modelled dynamic calculations is one of the key conclusions from the $\mathrm{CO}_{2}$ injection simulation. However, even if a reduction of the static capacity estimates is taken into account, it is clear that the Nordic region has substantial storage capacity in saline aquifers (Anthonsen et al. 2014; Lothe et al. 2015).

\section{Acknowledgements}

This article has been produced with support from NORDICCS, under the Top-level Research Initiative $\mathrm{CO}_{2}$ Capture and Storage programme, and Nordic Innovation. The authors acknowledge the following partners for their contributions: Statoil, Gassco, Norcem, Reykjavik Energy, $\mathrm{CO}_{2}$ Technology Centre Mongstad, Vattenfall and the Top-level Research Initiative (Project number 11029).

\section{References}

Anthonsen, K.L., Frykman, P. \& Nielsen, L.H. 2011: The potential for geological storage of $\mathrm{CO}_{2}$ in Denmark is very promising. In: Sønderberg Petersen, L. \& Larsen H. (eds): Energy systems and technologies for the coming century. Risø International Energy Conference 2011, May 10-12. Proceedings, 48-55.

Anthonsen, K.L., Aagaard, P., Bergmo, P.E.S., Gislason, S.R., Lothe, A.E., Mortensen, G.M. \& Snæbjörnsdottir, S.Ó. 2014: Characterisation and selection of the most prospective $\mathrm{CO}_{2}$ storage sites in the Nordic region. Energy Procedia 63, 4884-4896.

Gislason, S.R., Wolff-Boenisch, D., Stefansson, A., Oelkers, E.H., Gunnlaugsson, E., Sigurdardottir, H. \& Sigfussson, B. 2010: Mineral sequestration of carbon dioxide in basalt: A pre-injection overview of the CarbFix project. International Journal of Greenhouse Gas Control 4(3), 537-545.

Japsen, P. \& Langtofte, C. 1991: Geological map of Denmark 1:400 000. The Danish Basin: 'Top Trias' and the Jurassic - Lower Cretaceous. Danmarks Geologiske Undersøgelse Map Series 30.

Larsen M., Bidstrup T. \& Dalhoff, F. 2003: Mapping of deep saline aquifers in Denmark with potential for future $\mathrm{CO}_{2}$ storage. A GESTCO contribution. Danmarks og Grønlands Geologiske Undersøgelse Rapport 2003/39, 83 pp.

Lothe, A.E., Emmel, B., Bergmo, P.E., Mortensen, G.M. \& Frykman, P. 2015: Updated estimate of storage capacity and evaluation of seal for selected aquifers (D26). NORDICCS Technical report D 6.3.1401, $80 \mathrm{pp}$.

Michelsen, O., Nielsen, L.H., Johannessen, P.N., Andsbjerg, J. \& Surlyk, F. 2003: Jurassic lithostratigraphy and stratigraphic development onshore and offshore Denmark. In: Ineson, J.R. \& Surlyk, F. (eds): The Jurassic of Denmark and Greenland. Geological Survey of Denmark and Greenland Bulletin 1, 147-216.

Nielsen, L.H. 2003: Late Triassic - Jurassic development of the Danish Basin and the Fennoscandian Border Zone, southern Scandinavia. In: Ineson, J.R. \& Surlyk, F. (eds): The Jurassic of Denmark and Greenland. Geological Survey of Denmark and Greenland Bulletin 1, 459-526.

Røkke, N.A., Aarlien, R., Mazzetti, M., Kielland Haug, J.J., Skagestad, R., Onaeheim, K., Lund, H., Kjärstad, J. \& Anthonsen, K.L. in press: Final Report. NORDICCS, Nordic CCS Competence Centre. Nordic Innovation Publication.

Snæbjörnsdóttir, S.Ó., Wiese, F., Fridriksson, T., Ármannsson, H., Einarsson, G.M. \& Gislason, S.R. 2014: $\mathrm{CO}_{2}$ storage potential of basaltic rocks in Iceland and the oceanic ridges. Energy Procedia 63, 4585-4600.

Teir, S. et al. 2010: Potential for carbon capture and storage (CCS) in the Nordic region. VTT Tiedotteita - Research Notes 2556, 53-73.

Vangkilde-Pedersen, T. et al. 2009: Assessing European capacity for geological storage of carbon dioxide - the EU GeoCapacity project. Energy Procedia 1, 2663-2670. 